\title{
Perubahan kadar LDL dan HDL pada kelinci New Zealand White yang diberi ekstrak beras hitam (Oryza sativa L.)
}

\author{
${ }^{1}$ Jessica G. Runtu \\ ${ }^{2}$ Shirley E. S. Kawengian \\ ${ }^{2}$ Nelly Mayulu \\ ${ }^{2}$ Alexander S. L. Bolang \\ ${ }^{1}$ Kandidat Skripsi Fakultas Kedokteran Universitas Sam Ratulangi Manado \\ ${ }^{2}$ Bagian Gizi Fakultas Kedokteran Universitas Sam Ratulangi Manado \\ Email: jessicagruntu@gmail.com
}

\begin{abstract}
Cardiovascular disease, especially coronary heart disease (CHD), is the leading cause of death annually. Low HDL and high LDL levels are related to the increased risk of $\mathrm{CHD}$. Polyphenol such as anthocyanin in black rice could reduce the cardiovascular risks due to its antioxidant that has anti-platelet and anti-inflammatory activities. This study was aimed to determine the changes in LDL and HDL levels in rabbits fed with black rice extract (Oryza sativa L.). This was a true experimental study with a pretest posttest control group design. Samples were male New Zealand White rabbits, weighing 0.8-2.5 kg divided into four groups. Group A was fed with standard diet; group B was fed with high-fat diet; group C was fed with high-fat diet and black rice extract; and group D was fed with high-fat diet and atorvastatin. Data were presented descriptively. The results showed that the mean LDL level of group C increased by $6.5 \mathrm{mg} / \mathrm{dl}$ but one sample showed a decrease of $2 \mathrm{mg} / \mathrm{dl}$. The mean level of HDL of group C decreased $0.50 \mathrm{mg} / \mathrm{dl}$. This reduction was not as many as the other groups but one sample showed an increase of $5 \mathrm{mg} / \mathrm{dl}$. Conclusion: Not all rabbits fed with black rice extract showed decreased LDL level and increased HDL level.
\end{abstract}

Keywords: LDL, HDL, black rice extract

\begin{abstract}
Abstrak: Penyakit kardiovaskuler terutama penyakit jantung koroner (PJK) merupakan penyebab kematian tertinggi pertahunnya. Kadar HDL rendah serta kadar LDL tinggi berkaitan dengan meningkatnya risiko PJK. Polifenol seperti antosianin yang terdapat dalam beras hitam dapat menurunkan risiko penyakit kardiovaskular karena antioksidannya dengan aktivitas anti-platelet dan anti-inflamasi. Penelitian ini bertujuan untuk mengetahui perubahan kadar LDL dan HDL pada kelinci yang diberi ekstrak beras hitam (Oryza sativa L.). Jenis penelitian ialah true experimental dengan desain pre test post test control grup. Sampel ialah kelinci New Zealand White jantan, berat badan 0,8- 2,5 kg. Kelompok A diberi pakan standar; kelompok B diberi diet tinggi lemak; kelompok $\mathrm{C}$ diberi diet tinggi lemak dan ekstrak beras hitam; dan kelompok D diberi diet tinggi lemak dan atorvastatin. Data disajikan secara deskriptif. Hasil penelitian mendapatkan pada kelompok C, rerata kadar LDL meningkat 6,5 $\mathrm{mg} / \mathrm{dl}$ tetapi satu sampel mengalami penurunan sebesar $2 \mathrm{mg} / \mathrm{dl}$. Rerata kadar HDL pada kelompok C menurun $0,50 \mathrm{mg} / \mathrm{dl}$; penurunan ini tidak sebesar pada kelompok lainnya tetapi satu sampel mengalami peningkatan sebesar $5 \mathrm{mg} / \mathrm{dl}$. Simpulan: Kelinci yang diberi ekstrak beras hitam tidak semua mengalami penurunan kadar LDL dan peningkatan kadar HDL.
\end{abstract}

Kata kunci: LDL, HDL, Ekstrak beras hitam

Penyakit kardiovaskular merupakan Setiap tahunnya lebih banyak orang penyebab kematian nomor satu di dunia. meninggal akibat penyakit kardiovaskular 
dibandingkan akibat penyakit lainnya. ${ }^{1}$ Menurut World Health Organization (WHO) pada tahun 2012 diperkirakan 17,5 juta orang meninggal karena penyakit kardiovaskular, $31 \%$ dari seluruh kematian di dunia. Dari kematian ini, diperkirakan 7,4 juta ialah karena penyakit jantung koroner (PJK) dan 6,7 juta akibat stroke. ${ }^{1}$

Menurut data Centers for Disease Control and Prevention, penyakit kardiovaskular menjadi penyebab kematian utama di negara Amerika serikat pada tahun 2009, 2010, dan 2011. ${ }^{2}$ Di negara Indonesia sekitar 2.650.340 orang menderita PJK pada tahun 2013 dengan penderita terbanyak di Provinsi Jawa Barat sebanyak 160.812 orang, sedangkan Provinsi Maluku Utara memiliki jumlah penderita paling sedikit yaitu 1.436 orang. $^{3}$

Penelitian klinis menunjukkan PJK berkorelasi dengan ateroma (plak aterosklerosis) serta komplikasinya seperti trombosis. Juga telah dilaporkan bahwa perkembangan aterosklerosis disebabkan oleh interaksi yang kompleks antara reactive oxygen species (ROS), lipid, endotel, sirkulasi dan sel-sel inflamasi jaringan, platelet dan sel otot polos vaskular dan tidak hanya oleh penimbunan lemak. $^{4} \quad$ Penelitian lainnya mempelajari peran lipid darah dalam pengembangan aterosklerosis dan peningkatan risiko penyakit kardiovaskular. Kadar highdensity lipoprotein (HDL) yang rendah serta kadar low-density lipoprotein (LDL) yang tinggi dikaitkan dengan peningkatan risiko PJK. ${ }^{5}$

Penelitian sebelumnya yang dilakukan oleh Ling et al. ${ }^{6}$ melaporkan bahwa beras hitam dapat mengurangi pembentukan plak aterosklerosis akibat hiperkolesterolemia pada kelinci secara bermakna. Mekanisme ini terkait dengan kadar antioksidan dalam beras yang berpengaruh menurunkan siklus pembentukan LDL dan oksidasi membran lipid. $^{6}$

Seiring dengan meningkatnya kesadaran masyarakat akan kesehatan, konsumsi beras organik terus meningkat terutama beras berwarna karena kandungan pigmen warna yang bersifat sebagai antioksidan. $^{7}$ Kebutuhan beras organik sejak pada tahun 2005-2009 di Indonesia terus meningkat setiap tahunnya, mencapai 1.141.102 kuintal pada tahun $2009 .^{8}$

Beras hitam (Oryza sativa L.) merupakan sumber serat dan polifenol, terutama antosianin. Pada penelitian yang telah dilakukan sebelumnya, polifenol seperti antosianin yang terdapat dalam beras hitam dapat menurunkan resiko penyakit kardiovaskular karena bersifat sebagai antioksidan dengan aktivitas antiplatelet dan anti-inflamasi. ${ }^{9,10}$

Penelitian ini bertujuan untuk mengetahui perubahan kadar LDL dan HDL pada kelinci New Zealand White yang diberi esktrak beras hitam

\section{METODE PENELITIAN}

Penelitian ini dilaksanakan di Laboratorium Advance FMIPA Universitas Sam Ratulangi Manado selama bulan November 2015 hingga Januari 2016.

Jenis penelitian ialah true experimental dengan desain pre test post test control group. Penelitian ini menggunakan kelinci New Zealand White jantan dengan berat badan 0,8-2,5 kg. Jumlah sampel ditentukan dengan menggunakan rumus Federer ${ }^{11}$ dan diperoleh jumlah sampel minimal 6 ekor perkelompok. Dengan pertimbangan kemungkinan ada sampel yang mati maka ditambahkan 2 ekor sehingga total 8 ekor perkelompok dengan jumlah keseluruhan 32 ekor kelinci.

Sampel dibagi menjadi 4 kelompok perlakuan yaitu: kelompok A diberi pakan standar; kelompok B diberi pakan standar dan diet tinggi lemak; kelompok $\mathrm{C}$ diberi pakan standar, diet tinggi lemak, dan ekstrak beras hitam; kelompok D diberi pakan standar, diet tinggi lemak, dan atorvastatin.

Data kadar LDL dan HDL dikumpulkan dengan cara mengambil sampel darah semua kelinci di setiap kelompok sebelum dan sesudah perlakuan. Hasil disajikan secara deskriptif karena bnyaknya sampel yang mati hingga jumlah akhir sampel 12 ekor tidak memenuhi syarat untuk dilakukan analisis data. 
Sebelum diberi perlakuan, kelinci diadaptasi terlebih dahulu dengan diberi pakan standar, ditempatkan diruangan dengan temperature $24^{\circ} \mathrm{C}$, setiap kandang hanya ditempatkan 1 ekor kelinci. Pakan standar yang digunakan ialah Vitamax sesuai dengan Tabel $1 .^{12}$

Tabel 1. Dosis makanan kelinci ${ }^{12}$

\begin{tabular}{cc}
\hline $\begin{array}{c}\text { Berat kelinci } \\
(\mathrm{g})\end{array}$ & $\begin{array}{c}\text { Dosis makanan } \\
(\mathrm{g} / \mathrm{hari})\end{array}$ \\
\hline $740-1050$ & 84 \\
$1050-1395$ & 114 \\
$1395-1750$ & 136 \\
$1750-2085$ & 148 \\
$2085-2395$ & 160 \\
$2395-2680$ & 171 \\
\hline
\end{tabular}

Setelah adaptasi selama 14 hari, dilakukan pengukuran berat badan dan pengambilan sampel darah kelinci untuk memeriksa kadar LDL dan HDL. Sampel darah diambil dari pembuluh darah telinga kelinci menggunakan spuit $3 \mathrm{cc}$ dan needle 26G. Kelinci dikelompokkan dan dilakukan perlakuan sesuai kelompoknya. Selama masa adaptasi 3 ekor kelinci mati, sehingga hanya 29 ekor yang menjalani perlakuan.

Ekstrak beras hitam dibuat dengan cara maserasi menggunakan etanol $70 \%$ dan aquades selama $2 \times 24$ jam. Jumlah pemberian didasarkan pada dosis ekstrak beras hitam untuk mencit dengan berat badan $20 \mathrm{~g}$ yaitu $0,23 \mathrm{~g} / \mathrm{kg}$ bahan makanan. ${ }^{13}$ Dosis tersebut dikonversi dengan dosis pada kelinci dengan berat badan $1,5 \mathrm{~kg}$. Faktor konversi kelinci secesar 27,80 sehingga perhitungan dosis sebesar 6,394 $\mathrm{g} / \mathrm{kg}$ bahan makanan atau 0,64 g/100 g bahan makanan untuk kelinci dengan berat badan $1,5 \mathrm{~kg}$. Pada penelitian ini berat badan kelinci terendah $0,8 \mathrm{~kg}$ maka dosis ekstrak beras hitam 0,32 g/100 g bahan makanan.

Diet tinggi lemak dibuat dari lemak babi yang dipanaskan hingga mencair kemudian dicampurkan ke makanan kelinci dengan dosis $3 \mathrm{~g} / 100 \mathrm{~g}$ bahan makanan. Atorvastatin tablet digerus dan diberikan dengan dosis $0,016 \mathrm{~g} / \mathrm{kgBB}$.
Setelah 28 hari menjalani masa perlakuan, dilakukan pengukuran berat badan dan pengambilan sampel darah kelinci untuk menentukan kadar LDL dan HDL setelah perlakuan.

\section{HASIL PENELITIAN}

Tabel 2 memperlihatkan hewan coba pada masing-masing kelompok. Selama proses perlakuan, 17 ekor kelinci mati dari 29 ekor kelinci yang menjalani masa perlakuan. Pada akhir penelitian jumlah kelinci yang tersisa 12 ekor yang ditiap kelompok bervariasi jumlahnya; 12 kelinci ini yang diambil sampel darah sesudah perlakuan.

Tabel 3 menunjukkan perbedaan rerata berat badan kelinci sebelum dan sesudah perlakuan pada keempat kelompok. Peningkatan berat badan tertinggi pada kelompok A yaitu $49,41 \%$.

Tabel 4 menunjukkan perbedaan kadar LDL sebelum dan sesudah perlakuan pada keempat kelompok. Kelompok B mengalami peningkatan tertinggi sebesar 2155,55\% sedangkan kelompok D mengalami penurunan sebesar $89,07 \%$.

Tabel 5 menunjukkan perbedaan rerata kadar HDL sebelum dan sesudah perlakuan pada keempat kelompok. Kelompok A, C, dan $\mathrm{D}$ mengalami penurunan rerata kadar HDL. Peningkatan terbesar terjadi pada kelompok B mengalami peningkatan rerata kadar HDL sebesar 38\% sedangkan kelompok D menurun sebesar 36,46\%.

\section{BAHASAN}

Kelompok A dengan perlakuan pakan standar mengalami peningkatan berat badan tertinggi. Hal ini berbeda dengan penelitian yang dilakukan oleh Herlambang et al. ${ }^{11}$ yang mendapatkan peningkatan berat badan tertinggi terjadi pada kelompok yang diberikan diet tinggi lemak.

Pada kelompok $\mathrm{C}$ yang diberi perlakuan ekstrak beras hitam, kedua kelinci mengalami kenaikan berat badan tetapi tidak sebanyak pada kelompok A dan B. Hal ini disebabkan kandungan serat dalam beras hitam yang dapat memengaruhi rasa lapar kelinci. ${ }^{12,13}$ 
Tabel 2. Karakteristik sampel

\begin{tabular}{|c|c|c|c|}
\hline \multirow[t]{2}{*}{ Kelompok } & \multicolumn{2}{|c|}{ Jumlah sampel } & \multirow[t]{2}{*}{ Keterangan } \\
\hline & Sebelum perlakuan & Setelah perlakuan & \\
\hline A & 7 & 5 & 2 ekor mati \\
\hline B & 8 & 2 & 6 ekor mati \\
\hline $\mathrm{C}$ & 7 & 2 & 5 ekor mati \\
\hline $\mathrm{D}$ & 7 & 3 & 4 ekor mati \\
\hline
\end{tabular}

Tabel 3. Berat badan kelinci

\begin{tabular}{ccccc}
\hline \multirow{2}{*}{ Kelompok } & \multirow{2}{*}{ N } & \multicolumn{2}{c}{ Rerata BB \pm SD $(\mathrm{kg})$} & \multirow{2}{*}{ Sebelum } \\
& & $1,70 \pm 0,436$ & $2,54 \pm 0,351$ & 49,41 \\
A & 5 & $1,70 \pm 0,707$ & $2,50 \pm 0,707$ & 47,05 \\
B & 2 & $1,70 \pm 0,849$ & $2,35 \pm 0,778$ & 38,23 \\
C & 2 & $1,97 \pm 0,208$ & $2,57 \pm 0,252$ & 30,61 \\
D & 3 & &
\end{tabular}

Tabel 4. Rerata kadar LDL sebelum dan sesudah perlakuan

\begin{tabular}{ccccc}
\hline \multirow{2}{*}{ Kelompok } & \multirow{2}{*}{ N } & \multicolumn{2}{c}{ Rerata $L D L \pm$ SD $(\mathrm{mg} / \mathrm{dl})$} & $\Delta(\%)$ \\
& & Sebelum & Sesudah & \\
\hline $\mathrm{A}$ & 5 & $12,80 \pm 11,189$ & $13,20 \pm 13,312$ & 3,12 \\
$\mathrm{~B}$ & 2 & $4,50 \pm 0,707$ & $101,50 \pm 23,335$ & 2155,55 \\
$\mathrm{C}$ & 2 & $14,50 \pm 4,950$ & $21,00 \pm 16,971$ & 44,82 \\
$\mathrm{D}$ & 3 & $21,33 \pm 16,197$ & $2,33 \pm 2,309$ & 89,07 \\
\hline
\end{tabular}

Tabel 5. Rerata kadar HDL sebelum dan sesudah perlakuan

\begin{tabular}{ccccc}
\hline Kelompok & $\mathrm{N}$ & \multicolumn{2}{c}{ Rerata HDL $\pm \mathrm{SD}(\mathrm{mg} / \mathrm{dl})$} \\
Sebelum & $\Delta(\%)$ & \\
\hline $\mathrm{A}$ & 5 & $29.80 \pm 5,070$ & $29,40 \pm 8,173$ & 1,34 \\
$\mathrm{~B}$ & 2 & $25.00 \pm 14,142$ & $34,50 \pm 17,678$ & 38 \\
$\mathrm{C}$ & 2 & $26.50 \pm 19,092$ & $26,00 \pm 11,314$ & 1,88 \\
$\mathrm{D}$ & 3 & $32.00 \pm 1,000$ & $20,33 \pm 9,018$ & 36,46 \\
\hline
\end{tabular}

Rerata kadar LDL pada kelompok A yang diberi pakan standar mengalami peningkatan, tetapi sebagian kelinci pada kelompok ini mengalami penurunan kadar LDL sedangkan yang lain dengan kadar LDL tetap sama. Kelompok B yang diberi perlakuan diet tinggi lemak mengalami peningkatan kadar LDL yang jauh berbeda dengan sebelum dilakukan perlakuan. Hasil penelitian ini sejalan dengan penelitian yang dilakukan oleh Jawi et al. ${ }^{14}$ pada tikus Wistar yaitu pemberian lemak jenuh memengaruhi kadar LDL. Penelitian dilakukan oleh Jawi et al. ${ }^{14}$ mendapatkan makanan tinggi kolesterol memengaruhi kadar LDL hingga terjadi peningkatan yang bermakna.
Kelompok C yang diberi ekstrak beras hitam rerata kadar LDL mengalami peningkatan, tetapi dari kedua kelinci yang tersisa kelinci no.2 mengalami penurunan 2 mg/dl kadar LDL. Penurunan kadar LDL pada kelinci no.2 ini tidak sebesar penurunan yang terjadi pada kelompok D yang diberi diet atorvastatin.

Hasil yang didapatkan pada kelinci no.2 sesuai dengan penelitian sebelumnya yang menunjukkan bahwa antosianin yang terkandung dalam beras hitam dapat menyebabkan pengendapan kolesterol dari misel yang menyebabkan penurunan kolesterol. $^{15}$ Penelitian lainnya juga melaporkan penurunan kadar LDL pada tikus Wistar yang diberi ekstrak beras 
hitam. $^{11}$ Hasil penelitian yang dilakukan Ling et al. ${ }^{6}$ tidak mendapatkan perbedaan pada pemberian beras hitam dan merah pada kadar LDL-C dan kolesterol total.

Pada penelitian ini, rerata kadar HDL kelompok A mengalami penurunan sedangkan pada kelompok B terjadi peningkatan rerata kadar HDL yang terbesar, tetapi salah satu sampel mengalami penurunan kadar HDL.

Penelitian yang dilakukan Ling et al. ${ }^{6}$ mendapatkan penurunan lesi aterosklerosis yang menandakan bahwa beras hitam dan beras merah memiliki efek protektif terhadap aterosklerosis, juga terdapat kenaikan kadar kolesterol HDL. Pada penelitian ini, kelompok $\mathrm{C}$ yang diberi ekstrak beras hitam mengalami penurunan rerata kadar HDL tetapi dari kedua kelinci yang tersisa, kelinci no.23 mengalami peningkatan kadar HDL sebesar $5 \mathrm{mg} / \mathrm{dl}$.

Hasil yang didapatkan dari kelinci no.23 sesuai dengan penelitian sebelumnya yang dilakukan oleh Nelwan et al. ${ }^{16}$ terhadap tikus Wistar yaitu pemberian jus apel merah yang mengandung antosianin berpengaruh menaikkan kadar kolesterol HDL. ${ }^{19}$ Begitu juga dengan penelitian yang dilakukan pada kelinci yang diberi ekstrak air umbi jalar ungu, terjadi peningkatan kadar HDL yang bermakna karena kandungan antosianin didalam warna umbi. $^{14}$

Pada penelitian ini tidak dilakukan analisis statistik karena jumlah sampel yang tersisa pada akhir penelitian tidak sesuai dengan besar sampel yang ditargetkan. Penilaian perubahan kadar LDL dan HDL dengan konsumsi ekstrak beras hitam menjadi tidak sesuai karena kelompok ini hanya tersisa dua ekor kelinci pada akhir penelitian.

Keterbatasan penelitian yaitu cara pemberian ekstrak beras hitam tidak menggunakan nasogastric tube, melainkan ekstrak diencerkan dengan air dan ditaruh ditempat makanan kelinci sehingga sering terdapat sisa ekstrak yang tidak dihabiskan oleh kelinci. Banyak semut pada makanan kelinci mungkin membuat kelinci tidak menghabiskan makanannya. Tempat minum kelinci yang tidak dapat mengalirkan air dengan baik juga menyulitkan kelinci untuk minum.

Penyebab kematian banyak kelinci pada saat perlakuan belum diketahui secara pasti, tetapi ada beberapa faktor yang mungkin memengaruhi. Lingkungan kandang kelinci yang kurang bersih menyebabkan kelinci terserang diare yang berakibat kematian. Adanya tikus dalam ruangan kandang yang belum bisa dikontrol peneliti dapat menyebabkan stres pada kelinci. Selain itu terdapat faktor lain yang belum bisa dikendalikan dengan baik seperti aktivitas fisik, nafsu makan, dan lingkungan kandang kelinci.

Perlunya ruangan atau laboratorium hewan yang lebih khusus agar penyebab kematian kelinci atau hewan coba lainnya dapat diminimalkan. Diperlukan pula alatalat penunjang penelitian yang lebih baik agar ekstrak dan bahan lainnya dapat dikonsumsi oleh kelinci atau hewan coba secara maksimal.

\section{SIMPULAN}

Kelinci yang diberi ekstrak beras hitam tidak semua mengalami penurunan kadar LDL dan peningkatan kadar HDL.

\section{DAFTAR PUSTAKA}

1. World Health Organization. Cardio-vascular disease (CVDs). [cited 28 Juni 2016. Available from: http://www.who.int/mediacentre/factsh eets/fs317/en/.

2. Santulli G. Epidemiology of cardiovascular disease in the 21st century: Updated numbers and updated facts. $\mathbf{J}$ Cardiovasc Dis Res. 2013;1(1):1-2.

3. Riset Kesehatan Dasar 2013. Penyakit jantung. Badan Penelitian dan Pengembangan Kesehatan; p. 90-1.

4. Wang Q, Han PH, Zhang MW, Xia M, Zhu HL, Ma J, et al. Supplementation of black rice pigment fraction improves antioxidant and anti-inflammatory status in patients with coronary heart disease. Asia Pac J Clin Nutr 2007;16(Suppl 1):295-301.

5. Fuster V, Kelly BB. Promoting cardiovascular health in the developing world: A 
clinical challenge to achieve global health. Institute of Medicine of the National Academies: The National Academies Press Washington D.C, 2010; p. 83.

6. Ling WH, Wang LL, Ma J. Supplementation of the black rice outer layer fraction to rabbits decreases atherosclerotic plaque formation and increases antioxidant status. J Nutr. 2002;132:20-6.

7. Widyawati PS, Suteja AM, Suseno TIP, Monika P, Saputrajaya W, Liguori C. Pengaruh perbedaan Warna Pigmen Beras Organik Terhadap Aktivitas Antioksidan. AGRITECH 2014;34(4): 399-406.

8. Pertanian Sehat Indonesia. Tren konsumen beras organik meningkat. Semai (4th ed). 2012; p. 9. [cited 5 April 2016]. Available from: http://pertaniansehat.com/read/2012/05/ 28/tren-konsumen-beras-organikmeningkat.html.

9. Sa'adah I, Supriyanya R, Subejo. Keragaman warna gabah dan warna beras varietas lokal padi beras hitam (Oryza sativa L.) yang dibudidayakan oleh petani Kabupaten Sleman, Bantul dan Magelang. Vegetalika. 2013;2(3):13-20.

10. Zawistowski J, Kopec A, Kitts DD. Effects of a black rice extract (Oryza sativa L. indica) on cholesterol levels and plasma lipid parameters in Wistar Kyoto Rats. Journal of Functional Foods. 2009;1:
$50-6$.

11. Herlambang HA, Kapantouw NH, Kawengian SES. Perbandingan efektivitas pemberian ekstrak beras hitam dan ekstrak beras merah terhadap perubahan profil lipid tikus Wistar (Rattus novergicus). Jurnal Ilmu Teknologi Pangan. 2015;3(1):26-34.

12. Maertens L. Feeding system for intensive production. In: de Blas $\mathrm{C}$, Wiseman $\mathrm{J}$, editors. Nutrition of the Rabbit (2nd ed). United Kingdom: CABI, 2010; $p$. 257.

13. Jang HH, Park MY, Kim HW, et all. Black rice (Oryza sativa L.) extract attenuates hepatic steatosis in C57BL/6 J mice fed a high-fat diet via fatty acid oxidation. Nutrition and Metabolism. 2012;9(1):27.

14. Jawi IM, Budiasa K. Ekstrak air umbi ubi jalar ungu menurunkan total kolesterol serta meningkatkan total antioksidan darah kelinci. Jurnal Veteriner 2011;12(2):120-5.

15. Yao SL, Xu Y, Zhang YY, Lu YH. Black rice and anthocyanins induce inhibition of cholesterol absorption in vitro. Food and Function Journal. 2013;4:1602-08.

16. Nelwan G, Wullur AC, Bodhi W. Pengaruh jus buah apel merah (Pyrus malus L.) terhadap kadar kolesterol HDL (High Density Lipoprotein) darah tikus putih jantan galur Wistar (Rattus norvegicus). Pharmacon. 2012;1(2):132-9. 